\title{
Phytochemical Constituents Isolated from the Stem Bark of Bauhinia monandra
}

\author{
Jailton Ferrari ${ }^{1}$ (D), Djalma Menezes de Oliveira² $^{2}$ (D), Nadia Machado Aragão² \\ ${ }^{1}$ Departamento de Química, Universidade Federal da Paraíba - UFPB, João Pessoa/PB, Brasil \\ ${ }^{2}$ Departamento de Química e Exatas, Universidade Estadual do Sudoeste da Bahia - UESB, Jequié/BA, Brasil
}

\begin{abstract}
The methanolic extract from stem bark of Bauhinia monandra, a medicinal plant employed in folk medicine, yielded by column chromatography lup-20(29)-en-3ß,24-diol (1) and methyl galloate (2) along with $\beta$-sitosterol (3). These known phytoconstituents are being reported for the first time from this plant and their structures were established by NMR and MS spectral studies and by comparison with their literature data. Furthermore, lup-20(29)-en-3 $\beta, 24$-diol (1), a minor constituent, was isolated from this genus for the first time.
\end{abstract}

Keywords: phytoconstituents, Leguminosae, methanolic extract. 


\section{INTRODUCTION}

Bauhinia species belongs to the Leguminosae family and includes approximately 300 species cultivated in tropical areas worldwide (Cechinel-Filho, 2009; Silva \& Cechinel-Filho, 2002). In Brazil, these plants are known by the vernacular name cow's foot or cow's paws due to the unique bilobed shape of their leaves (Santos et al., 2014). Several pharmacological proprieties and biological activities have been reported for Bauhinia species (Cechinel-Filho, 2009) among them we can highlight, for example, antioxidant (Santos et al., 2014; Aderogba et al., 2006; Argolo et al., 2004), antidiabetic (Alade et al., 2012; Frankish et al., 2010; Almeida et al., 2006; Estrada et al., 2005; Fuentes et al., 2004), anti-inflammatory and cytotoxic (Taweel et al., 2015; Boonphong et al., 2007). Furthermore, pharmacological and phytochemical investigations with plants of this genus are ongoing and as a result of these efforts, different classes of metabolites have been isolated and identified, including, for example, phenolic acids and esters (Taweel et al., 2015; Shang et al., 2006), glicolipids (Mendes et al., 2006), lactones, flavonoids, terpenoids, glucosyl steroids, steroids, tannins and quinines (Silva \& Cechinel-Filho, 2002; Menezes et al., 2007).

The plant Bauhinia monandra is a leguminous tree with large leaves and pink flowers with red dots (Agbugui et al., 2010), commonly used in ornamental gardens (Anhwang et al., 2005), as nutritional source of vitamin A (Balogun \& Fetuga, 1985) and in application to forage (Ilkiu-Borges \& Mendonça, 2009). This plant is in general found in West Africa and India (Agbugui et al., 2010; Anhwang et al., 2005), but it also can be found in South America, especially in Brazil where it is indicated among other uses as a natural antidiabetic medicine (Menezes et al., 2007; Macêdo et al., 2008). According to studies disclosed in the literature, the utilization of Bauhinia monandra as well as several other species of this genus (Silva \& Cechinel-Filho, 2002) as a hypoglycemic agent was possible because of the presence of flavonoids, such as a glycones or glycosides, which have been isolated from Bauhinia species (Cechinel-Filho, 2009; Menezes et al., 2007). The plant hypoglycemic activity of this genus has already been reported over 80 years ago. However, only recently have studies linking the decreasing blood glucose levels in normal and diabetic rats administered orally with one pure chemical constituent (kaempferitrin) purified from leaves of a Bauhinia specie appeared in the literature (Cechinel-Filho, 2009).

As a result of pharmacological importance that the Bauhinia genus has demonstrated in recent years, especially in herbal medicine, our research group decided to conduct a phytochemical study of the stem bark of Bauhinia monandra. This plant is cultivated in Jequié city, state of Bahia, Northeast of Brazil, for both ornamental purposes as herbal medicine. The specimen studied was collected from the garden of our university campus in Jequié City.

\section{MATERIAL AND METHODS}

\subsection{General procedures}

NMR spectra were obtained for ${ }^{1} \mathrm{H}$ at $300 \mathrm{MHz}$ and for ${ }^{13} \mathrm{C}$ at $75 \mathrm{MHz}$ using a Varian Gemini 300 spectrometer. Chemical shifts are reported in ppm units downfield from internal TMS reference and coupling constants $(J)$ reported in Hertz. The FTIR spectrum was recorded on a JASCO spectrophotometer Mod. Valor III. MS were recorded on a HP model 5973 spectrometer (EI-MS). Melting points were determined on a Microquímica MQAPF 301 hot plate apparatus and are uncorrected. Column Chromatography was performed using silica gel 60. Thin Layer Chromatography was carried out on precoated TLC plates and was used to monitor the isolation and purification process. The visualization of spots was achieved by UV ( 254 and $366 \mathrm{~nm}$ ), Libermann-Buchard spray reagent, and exposure to iodine vapor.

\subsection{Plant material}

The plant materials of $B$. monandra were collected from ornamental trees in the UESB (Universidade Estadual do Sudoeste da Bahia) garden in the city of Jequié - BA, Northeast of Brazil. The plant was authenticated by the staff of the Herbarium Alexandre Leal Costa, from UFBA (Universidade Federal da Bahia), where a voucher specimen (\#038524) has been deposited.

\subsection{Extraction and isolation}

Stem barks of B. monandra (620 g) were air-dried at room temperature, powdered, and macerated exhaustively in methanol for two weeks at room 
temperature. After filtration and solvent removal under reduced pressure, the methanolic extract was then re-suspended in methanol/distilled water (9:1) and partitioned with hexane $(0.11 \mathrm{~g})$, chloroform $(2.62 \mathrm{~g})$, ethyl acetate (1.24 g) and $n$-butanol (13.64 g), respectively. The chloroform soluble extract was subjected to silica gel column chromatography and eluted with mixture of $\mathrm{CHCl}_{3}: \mathrm{MeOH}(95: 2 \mathrm{v} / \mathrm{v})$ to give 175 fractions of $10 \mathrm{~mL}$ each, which were combined into five sub-fractions (SFC1-SFC5) from similar chromatographic profiles in TLC. The sub-fraction SFC1 $(297.4 \mathrm{mg}$ ), resulting from the combination of fractions 6 to 17 showed one major spot on TLC by spraying Liebermann-Buchard reagent. It was further subjected to column chromatography using $\mathrm{CHCl}_{3}: \mathrm{MeOH}(99: 1 \mathrm{v} / \mathrm{v})$ as eluent to afford a white crystalline solid $(90 \mathrm{mg})$, which was identified as compound $\mathbf{3}$ on the basis of its spectral data and in comparison of spectral properties acquired from authentic sample of $\beta$-sitosterol. The sub-fraction SFC2 (425.4 mg), resulting from the combination of fractions 18 to 50 was further purified by isocratic column chromatography eluting with $n$-hexane:EtOAc $(96: 4 \mathrm{v} / \mathrm{v})$ to give 53 fractions ( $10 \mathrm{~mL}$ each) monitored by comparative TLC, which were combined into five new sub-fractions (SFC2i-SFC2 $v$ ). The fraction SFC2 $i(10 \mathrm{mg})$, resulting from the combination of fractions 2 to 7 provided white needles and found to be homogeneous compound when it was subjected to TLC using several eluent systems and was characterized as compound $\mathbf{1}$ on the basis of its spectral data and in comparison of spectral properties reported from the literature (Tanaka et al., 1988). The fraction SFC2iii $(34.7 \mathrm{mg})$, in turn obtained by combining of fractions 16 to 30 , furnished the known compound methyl galate 2 (Hisham et al., 2011).

Lup-20(29)-en-33,24-diol (1): White needles (10 mg, 0.0016\%); m.p. $245-247^{\circ} \mathrm{C}$; IR bands (KBr): 3600-3100, 3050, 1640,1042 and $879 \mathrm{~cm}^{-1} ;{ }^{1} \mathrm{H}-\mathrm{NMR}\left(300 \mathrm{MHz}, \mathrm{CDCl}_{3}\right): \delta 4.68$ $(1 \mathrm{H}, \mathrm{d}, J=2.8 \mathrm{~Hz}, \mathrm{H}-29), \delta 4.60(1 \mathrm{H}, \mathrm{d}, J=2.8 \mathrm{~Hz}, \mathrm{H}-29)$, $\delta 4.21(2 \mathrm{H}, \mathrm{d}, J=12 \mathrm{~Hz}, \mathrm{H}-24), \delta 3.27(2 \mathrm{H}, \mathrm{d}, J=12 \mathrm{~Hz}, \mathrm{H}-24)$, $\delta 3.41(1 \mathrm{H}, \mathrm{dd}, J=11.0$ and $5.9 \mathrm{~Hz}, \mathrm{H}-3), \delta 1.74$ $(3 \mathrm{H}, \mathrm{s}, \mathrm{H}-30), \delta 1.31$ (3H, s, H-23), $\delta 1.10$ (3H, s, H-26), $\delta 0.91(3 \mathrm{H}, \mathrm{s}, \mathrm{H}-27), \delta 0.77$ (3H, s, H-28), $\delta 0.75$ $(3 \mathrm{H}, \mathrm{s}, \mathrm{H}-25) ;{ }^{13} \mathrm{C}-\mathrm{NMR}\left(75 \mathrm{MHz}, \mathrm{CDCl}_{3}\right): \delta 38.9$ (C-1), $\delta 27.7$ (C-2), $\delta 79.3$ (C-3), $\delta 43.0$ (C-4), $\delta 55.5$ (C-5), $\delta 18.5$ (C-6), $\delta 34.5$ (C-7), $\delta 41.0$ (C-8), $\delta 50.6$ (C-9), $\delta 38.2$ (C-10), $\delta 21.1$ (C-11), $\delta 25.3$ (C-12), $\delta 37.3$
(C-13), $\delta 43.0$ (C-14), $\delta 27.6$ (C-15), $\delta 35.8$ (C-16), $\delta 43.2$ (C-17), $\delta 48.2$ (C-18), $\delta 48.5$ (C-19), $\delta 151.1$ (C-20), $\delta 29.9$ (C-21), $\delta 40.2$ (C-22), $\delta 22.9$ (C-23), $\delta 63.4$ (C-24), $\delta 15.6$ (C-25), $\delta 16.4$ (C-26), $\delta 14.8$ (C-27), $\delta 18.2$ (C-28), $\delta 109.5$ (C-29), $\delta 19.5$ (C-30); MS m/z (rel. int.): $442[\mathrm{M}]^{+}\left(\mathrm{C}_{30} \mathrm{H}_{50} \mathrm{O}_{2}\right), 427,424,229$, $218,205,203,189,81$ (100\%). The data were similar to those of literature data (Tanaka et al., 1988).

Methyl gallate (2): White amorphous solid (34.7 mg, 0.0056\%); m.p. 196-198 ${ }^{\circ} \mathrm{C} ;{ }^{1} \mathrm{H}-\mathrm{NMR}(300 \mathrm{MHz}$, $\left.\mathrm{CD}_{3} \mathrm{OD}\right): \delta 7.12(2 \mathrm{H}, \mathrm{s}, \mathrm{H}-2, \mathrm{H}-6), \delta 3.81(3 \mathrm{H}, \mathrm{s},-\mathrm{Me})$; ${ }^{13} \mathrm{C}-\mathrm{NMR}\left(75 \mathrm{MHz}, \mathrm{CD}_{3} \mathrm{OD}\right): \delta 121.4(\mathrm{C}-1), \delta 110.3$ (C-2, 6), $\delta 146.3$ (C-3, 5), $\delta 139.6$ (C-4), $\delta 169.0$ (COO-), $\delta 52.3$ (-Me); MS m/z (rel. int.): $184[\mathrm{M}]^{+}\left(\mathrm{C}_{8} \mathrm{H}_{8} \mathrm{O}_{5}\right)$, $167,153(100 \%), 125,107,95,79$. The data were equal to those of literature data (Hisham et al., 2011).

$\beta$-Sitosterol (3): White needles (90 mg, 0.0145\%); m.p. $124-127^{\circ} \mathrm{C}$ (methanol); IR bands (KBr): 3435 , $2967,2932,2888,1469,1386,1068,1050 \mathrm{~cm}^{-1}$. The data were consistent with the authentic sample of $\beta$-sitosterol and literature data (Aragão et al., 1990).

\section{RESULTS AND DISCUSSION}

In order to contribute with phytochemicals studies of genus Bauhinia, and especially for the plant B. monandra, we initially investigated the methanolic extract of B. monandra stem barks. Thus, the methanolic extract was successively treated with hexane, chloroform, ethyl acetate and $n$-butanol, respectively. The chromatographic fractionation of the chloroform fraction from crude methanolic extract allowed us to isolate and identify three phytochemical constituents, being one triterpene (1), one phenolic compound (2), and one steroid (3). Although these phytochemical constituents are known chemical compounds, to the best of our knowledge, they were isolated for the first time from stem bark of B. monandra and their chemical structures are shown in Figure 1. Furthermore, among them, the lup-20(29)-en-3 $\beta, 24$-diol (1) was isolated also for the first time from genus Bauhinia.

Phytoconstituent $\mathbf{1}$ was isolated as white needles. The ${ }^{1} \mathrm{H}-\mathrm{NMR}$ spectrum from isolated compound $\mathbf{1}$ demonstrated characteristic signal of lupene-type triterpene, five ternary methyl groups, one isoprenyl $(\delta 4.68,4.60$, and 1.74$)$, one oxymethine hydrogen $(\delta 4.41)$, and oxymethylene hydrogens ( $\delta 4.21$, and 3.27$)$. 


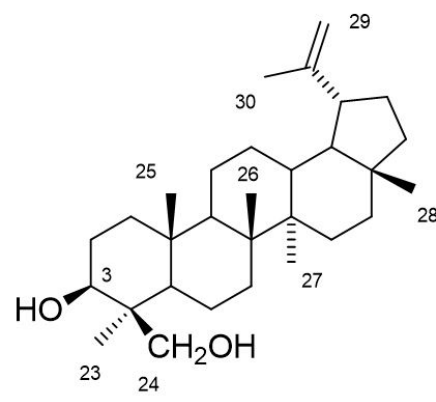

1<smiles>COC(=O)c1cc(O)c(O)c(O)c1</smiles>

2

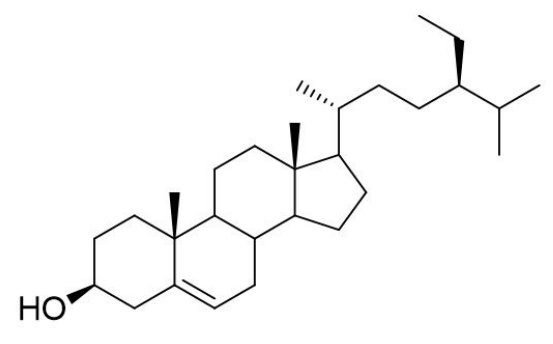

3

Figure 1. Phytochemical constituents (1,2 and 3) isolated from the stem bark of Bauhinia monandra.

The ${ }^{13} \mathrm{C}-\mathrm{NMR}$ spectrum (BB and DEPT $135^{\circ}$ ) displayed 30 resonances signals and supports the attributions in the ${ }^{1} \mathrm{H}-\mathrm{NMR}$ spectra via the resonances observed at $\delta 19.5,109.5,151.1,79.3$, and 63.4 for the isoprenyl, oxymethine, and oxymethylene groups, respectively. We propose the molecular formula $\mathrm{C}_{30} \mathrm{H}_{50} \mathrm{O}_{2}$ for lupene-type triterpene that was in agreement with $[\mathrm{M}]^{+} 442$ observed from EI-MS. Added to this, the IR spectrum of 1 showed strong absorption bands attributed to hydroxyl groups at $3600-3100 \mathrm{~cm}^{-1}$. These spectral data were directly compared with those described in literature for lup-20(29)-en-3 $\beta, 24$-diol (Tanaka et al., 1988), and they are similar allowing the identification of compound $\mathbf{1}$. Up until now there are no reports wherein the lup-20(29)-en-3 $\beta, 24$-diol has been isolated from Bauhinia genus.

It is noteworthy also that compound $\mathbf{1}$ was a minor constituent among the three substances found from chloroform fraction of stem bark crude methanolic extract, just $0.0016 \%$ based on dried and powdered botanical material (see experimental part).

Phytoconstituent 2 was isolated as white amorphous solid. The ${ }^{1} \mathrm{H}-\mathrm{NMR}$ spectrum from 2 showed a singlet at $\delta 7.12$ which integrated for two equivalents aromatic protons, and a singlet at $\delta 3.81$ which integrated for three methyl protons in the methoxy substituent. Added to this, the ${ }^{13} \mathrm{C}-\mathrm{NMR}$ spectrum demonstrated seven types of resonances signals, including an ester carbonyl group at $\delta$ 169.0, besides six others typical of aromatic carbons. These spectral data were directly compared with those described in literature for methyl gallate
(Hisham et al., 2011), and they are identical allowing the identification of compound 2 .

Phytoconstituent 3 was isolated as white needles. Spectrometric analysis of IR and melting point of 3 were consistent with the authentic sample of $\beta$-sitosterol, and also when compared with literature data (Aragão et al., 1990). Besides, Libermann-Buchard test indicated phytoconstituent 3 is having a sterol skeleton. To the best of our knowledge, this is the first study which identifies $\beta$-sitosterol in organic extract from stem bark of B. monandra.

\section{CONCLUSION}

In summary, three phytoconstituents were isolated and purified from methanolic extract of B. monandra stem bark, and then identified as lup-20(29)-en$3 \beta, 24$-diol (1), methyl gallate (2) and $\beta$-sitosterol (3). The present study is the first report to investigate phytochemical composition of B. monandra stem bark, and contributes to amplification of phytochemical knowledge of Bauhinia genus.

\section{ACKNOWLEDGEMENTS}

The authors are grateful for the logistic support provided by UESB (State University of Southwest Bahia) and Department of Organic Chemistry from UFBA (Federal University of Bahia) for NMR and EI-MS measurements. We also thank Prof. Jason G. Taylor (DQ/UFOP), for helpful suggestions about English grammar. 


\section{SUBMISSION STATUS}

Received: 14 dec., 2015

Accepted: 24 jan., 2018

\section{CORRESPONDENCE TO}

\section{Jailton Ferrari}

Departamento de Química, Centro de Ciências Exatas e da Natureza, Universidade Federal da Paraíba - UFPB, Campus I, Cidade Universitária, s/n, CEP 58051-900, João Pessoa, PB, Brasil e-mail: jailtonferrari@gmail.com; jferrari@quimica.ufpb.br

\section{REFERENCES}

Aderogba MA, Ogundaini AO, Eloff JN. Isolation of two flavonoids from Bauhinia Monandra (KURZ) leaves and their antioxidative effects. African Journal of Traditional, Complementary, and Alternative Medicines 2006; 3(4): 59-65. http://dx.doi.org/10.4314/ajtcam.v3i4.31177.

Agbugui M, Oniye SJ, Auta J. Effects of processing on the mineral content, proximate composition and phytochemical factors of the seeds of bauhinia monandra (kurz). Bayero Journal of Pure and Applied Sciences 2010;3(1):23. http:// dx.doi.org/10.4314/bajopas.v3i1.58558.

Alade GO, Adebajo AC, Omobuwajo OR, Proksch P, Verspohl EJ. Quercetin, a minor constituent of the antihyperglycemic fraction of Bauhinia monandra leaf. Journal of Diabetes 2012; 4(4): 439-441. http://dx.doi. org/10.1111/j.1753-0407.2012.00222.x. PMid:22742491.

Almeida ER, Guedes MC, Albuquerque JF, Xavier H. Hypoglycemic effect of Bauhinia cheilandra in rats. Fitoterapia 2006; 77(4):276-278. http://dx.doi.org/10.1016/j. fitote.2006.03.001. PMid:16713131.

Anhwang BA, Ajibola VO, Oniye SJ. Composition of bulk, trace and some rare earth elements in the seeds of Moringa oleifera (Lam) Detarium microcarpum (Guill and Perr) and Bauhinia monandra (Kurz). Journal of Food Technology 2005; 3(3): 290-293.

Aragão PCA, Toledo JB, Morais AA, Braz-Filho R. Substâncias naturais isoladas de Stigmaphyllon tormentosum e Byrsonima variabilis. Química Nova 1990; 13(4):254-259.

Argolo AC, Sant'Ana AE, Pletsch M, Coelho LC. Antioxidant activity of leaf extracts from Bauhinia monandra. Bioresource Technology 2004; 95(2): 229-233. http://dx.doi.org/10.1016/j. biortech.2003.12.014. PMid:15246449.

Balogun A, Fetuga BL. Fatty acid composition of seed oils of some members of the leguminosae family. Food Chemistry 1985; 17(3): 175-182. http://dx.doi.org/10.1016/03088146(85)90066-4.
Boonphong S, Puangsombat P, Baramee A, Mahidol C, Ruchirawat S, Kittakoop P. Bioactive compounds from Bauhinia purpurea possessing antimalarial, antimycobacterial, antifungal, anti-inflammatory, and cytotoxic activities. Journal of Natural Products 2007; 70(5): 795-801. http:// dx.doi.org/10.1021/np070010e. PMid:17480099.

Cechinel-Filho V. Chemical composition and biological potential of plants from the genus Bauhinia. Phytotherapy Research 2009; 23(10): 1347-1354. http://dx.doi.org/10.1002/ ptr.2756. PMid:19170142.

Estrada O, Hasegawa M, Gonzalez-Mujíca F, Motta N, Perdomo E, Solorzano A et al. Evaluation of flavonoids from Bauhinia megalandra leaves as inhibitors of glucose6-phosphatase system. Phytotherapy Research 2005; 19(10): 859-863. http://dx.doi.org/10.1002/ptr.1703. PMid:16261515.

Frankish N, de Sousa-Menezes F, Mills C, Sheridan H. Enhancement of insulin release from the beta-cell line INS- 1 by an ethanolic extract of Bauhinia variegata and its major constituent roseoside. Planta Medica 2010; 76(10): 995-997. http://dx.doi.org/10.1055/s-0029-1240868. PMid:20143296.

Fuentes O, Arancibia-Avila P, Alarcón J. Hypoglycemic activity of Bauhinia candicans in diabetic induced rabbits. Fitoterapia 2004; 75(6): 527-532. http://dx.doi.org/10.1016/j. fitote.2004.03.013. PMid:15351105.

Hisham DMN, Lip JM, Noh JM, Normah A, Nabilah MFN. Identification and isolation of methyl gallate as a polar chemical marker for Labisia pumila Benth. Journal of Tropical Agriculture and Food Science 2011; 39(2): 279-284.

Ilkiu-Borges F, Mendonça MS. Morfo-anatomia da semente de Bauhinia monandra Kurz: (Leguminosae-caesalpinioideae). Revista Brasileira de Sementes 2009; 31(4): 168-174. http:// dx.doi.org/10.1590/S0101-31222009000400020.

Macêdo MFS, Sisenando HAAACN, Queiroz JDF, Argolo ACC, Saturnino ACRD, Coelho LCBB et al. Determining the genotoxicity of an aqueous infusion of Bauhinia monandra leaves. Revista Brasileira de Farmacognosia 2008; 18(4): 509-516. http://dx.doi.org/10.1590/S0102695X2008000400002.

Mendes BG, Machado MJ, Falkenberg M. Triagem de glicolipídios em plantas medicinais. Revista Brasileira de Farmacognosia 2006; 16(4): 528. http://dx.doi.org/10.1590/ S0102-695X2006000400022.

Menezes FS, Minto ABM, Ruela HS, Kuster M, Sheridan H, Frankish N. Hypoglycemic activity of two Brazilian Bauhinia species: Bauhinia forficata L. and Bauhinia monandra Kurz. Revista Brasileira de Farmacognosia 2007; 17(1): 8-13. http://dx.doi.org/10.1590/S0102695X2007000100003.

Santos PM, Almeida PDO, Lima ES, Moraes MO, Costa PM, Meira AS et al. Perfil de flavonoides e avaliação do potencial antioxidante e citotóxico de Bauhinia purpurea 
(Fabaceae) da região amazônica. Química Nova 2014; 37(1): 89-94. http://dx.doi.org/10.1590/S0100-40422014000100017.

Shang XY, Li S, Wang YH, Wang SJ, Yang YC, Shi JG. Chemical constituents of Bauhinia aurea. Zhongguo Zhongyao Zazhi 2006; 31(23): 1953-1955. PMid:17348187.

Silva KL, Cechinel-Filho V. Plantas do gênero Bauhinia: composição química e potencial farmacológico. Química Nova 2002; 25(3): 449-454. http://dx.doi.org/10.1590/ S0100-40422002000300018.
Tanaka R, Tabuse M, Matsunaga S. Triterpenes from the stem bark of Phyllanthus flexuosus. Phytochemistry 1988; 27(11): 3563-3567. http://dx.doi.org/10.1016/00319422(88)80769-6.

Taweel AMA, Shafae AME, Perveen S, Fawzy GA, Khan SI. Anti-inflammatory and cytotoxic constituents of Bauhinia retusa. International Journal of Pharmacology 2015; 11(4): 372-376. http://dx.doi.org/10.3923/ ijp.2015.372.376. 